УДК: $502.75(477.54)$

Філатова O.B. http://orcid.org/0000-0003-0507-8192

Гонтова T.M. http://orcid.org/0000-0003-3941-9127; Scopus 55831710100

Руденко В.П. http://orcid.org/0000-0003-0018-2134

\title{
РЕПРЕЗЕНТАТИВНІСТЬ РІДКІСНОЇ ФІТОБІОТИ НА ЗАПОВІДНИХ ТА ПЕРСПЕКТИВНИХ ДЛЯ ЗАПОВІДАННЯ ТЕРИТОРІЯХ ЗАЧЕПИЛІВСЬКОГО РАЙОНУ ХАРКІВЩИНИ
}

\author{
(C) Філатова О. В., Гонтова Т.М., Руденко В.П. \\ Національний фармацевтичний університет, м. Харків \\ ztaxon@i.ua \\ tetianaviola@ukr.net \\ vprudenko58@gmail.com
}

https://doi.org/10.34142/ 2708-583X.2019.21.05

\begin{abstract}
У статті наведені результати вивчення фітобіоти 5 заповідних територій Зачепилівського району Харківщини та 5 перспективних для заповідання, щзо заплановано створити у складі екомережі. Майже всі обстежені території збереглися у мало порушеному стані. Вони повною мірою репрезентують природну рослинність регіону досліджень: справжні та чагарникові степи, заплавні дубові та вільхові ліси, справжні, засолені та болотисті луки, прибережно-водну та водну рослинність. До складу рідкісної фітобіоти належать 13 охоронюваних рослинних угруповань, 3 з яких (Stipeta capillatae, Stipeta lessingianae, Stipeta borysthenicae), занесені до Зеленої книги України та 26 видів раритетної флори, 10 з яких занесені до Червоної книги України: Anacamptis palustris (Jacq.) R.M. Bateman, Pridgeon et M.W. Chase, Crambe aspera M. Bieb., Dactylorhiza maculata (L.) Soo s.l., Gladiolus tenuis M. Bieb., Fritillaria meleagroides Patrin ex Schult. et Schult.f., Ornithogalum boucheanum (Kunth) Asch., Stipa borysthenica Klokov ex Prokudin, S. capillata L., S. lessingiana Trin. et Rupr., Tulipa quercetorum Klokov et Zoz. Найбільший ступінь раритетного фіторізноманіття відмічений на території водно-болотного угіддя «Заплава р. Оріль», де зростають 2 угруповання з Зеленої книги України, 4 угруповання з Зеленого списку Харківщини, 6 рідкісних видів з Червоної книги України та 8 - з Червоного списку Харківщини.

Ключові слова: рідкісні види флори, охоронювані рослинні угруповання, екологічна мережа, природнозаповідний фонд, Харківська область.
\end{abstract}

\section{ВСТУП}

Актуальність вивчення різноманіття у природних $[9,10]$ та урбанізованих заповідних [8] ландшафтах є загально визнаними у світі. Дослідження біоти Зачепилівського району Харківщини переважно присвячені орнітофауні. Загальні сучасні відомості про поширення окремих видів флори у межах Харківської області $є$ в роботі Л.М. Горєлової та О.О. Альохіна [2], біота Орільського екокоридору описана у роботі Г. С. Надточій, О. В. Філатової та О. В. Клімова [4]. Ці публікації носять фрагментарний характер. Обмежена загальна довідникова інформація про території природно-заповідного фонду (ПЗФ) та запроектованої екологічної мережі Харківської області $\epsilon$ у підготовлених Науково-дослідною установою «Український науководослідний інститут еколо-гічних проблем» (УКРНДІЕП) виданнях [5, 6]. Докладна інформація про рідкісну фітобіоту Заче-пилівського району у літературних джерелах відсутня.

Метою нашої роботи було вивчення сучасного стану рідкісної фітобіоти заповідних та перспективних для заповідання об’єктів одного 3 
найбільш розораних районів Харківщини - Зачепилівського.

\section{МАТЕРІАЛИ ТА МЕТОДИ ДОСЛУДЖЕНЬ}

Зачепилівський район розташований на крайньому півден-ному заході Харківщини у ЛівобережноДніпровсько-Приазовській північностеповій фізико-географічній провінції, в межах південно-західного схилу Дніпро-всько-Донецької западини. Територія має вигляд плато, яке має нахил на південний схід, та розчленоване річковими долинами, балками й схиловими ярами, межує 3 Полтавською та Дніпропетровською областями України. Річки належать до басейну Дніпра: Оріль 3 притоками Орчиком, Берестовою, найбільші озера: Лиман, Кругле, Гниле.

За геоботанічним районуванням [1] Зачепилівський район належить до Європейсько-Азіатської степової області Дніпровсько-Донецького геоботанічного округу різнотравнотипчаково-ковилових степів, байрачних дубових лісів, заплавних лук та лучно-галофітної рослинності на лесових терасах, Царичанського (Орільського) району терасових багаторізнотравно-типчаково-ковилових степів, заплавних луків та лучно-солончакової рослинності. У грунтовому покриві переважають чорноземи звичайні середньо-гумусні. На річкових терасах поширені чорноземні грунти на пісках та чорноземно-лучні солонцю-ваті грунти, невеликі ділянки займають піски. У доагрокультурний період тут панували різнотравно-ковиловотипчакові степи. Зараз понад 70\% грунтів розорані, лісистість наближається до 2\%. Це на 58\% заплавні та байрачні діброви із домінуванням Quercus robur L., трапляється Tilia cordata Mill., Fraxinus excelsior L., види Acer L. Соснові ліси із Pinus sylvestris L. мало поширені i приурочені до піщаних терас річок.

Ботанічні дослідження проводили протягом 1995-2014 рр. при виконанні наукової тематики УКРНДІЕП задля створення кадастру природно-заповідного фонду (ПЗФ) та оптимізації мережі заповідних територій, створення екологічної мережі Харківської області. Експедиційні виїзди 3 ботаніками лабораторії проблем природних територій та об'єктів особливої охорони В.В. Твєретиновою, О.Г. Вовк, М.С. Улановським здійснювали під керівництвом завідуючого лабораторією О.В. Клімова на території існуючих об'єктів ПЗФ та мало порушених природних територій регіону досліджень, що можуть бути включені до екомережі - землі заплавних та надзаплавних терас. Фітосозологічні дослідження передбачали визначення типу рослинності, переважаючих та рідкісних рослинних угруповань із Зеленої книги України (ЗКУ) [3] та Зеленого списку Харківщини (3СХ) [5], флористичного складу рідкісної біоти, зокрема: видів рослин, занесених до Червоної книги України (ЧКУ) [7] та Червоного списку Харківської області (ЧСХ) [5]. Обов'язково визначали ступінь збереження рослинності в при-родному стані та антропогенний впливу на біоту. 


\section{РЕЗУЛЬТАТИ}

На 2019 р. до ПЗФ Зачепилівського району належать 5 об'єктів (табл. 1). Серед них переважають зоологічні заказники місцевого значення (ЗМ3) загальнозоологічний, орнітологічний та 2 ентомологічні, а також $\epsilon$ гідрологічний. Найбільшу площу має загальнозооогічний заказник «Орчик». Він складається з трьох урочищ, що відрізняються рослинним покривом.

Загальна характеристика обстежених об'єктів ПЗФ

\begin{tabular}{|c|c|c|c|c|}
\hline Назва об’єкта & Категорія & $\begin{array}{c}\text { Площа, } \\
\text { га }\end{array}$ & Типи рослинності & $\begin{array}{c}\text { Антропогенний } \\
\text { вплив }\end{array}$ \\
\hline \multicolumn{5}{|c|}{ Існуючі об’єкти ПЗФ } \\
\hline $\begin{array}{l}\text { Руський } \\
\text { Російський } \\
\text { Орчик }\end{array}$ & $\begin{array}{c}\text { Загальнозоологі } \\
\text { чний 3М3 }\end{array}$ & 1006.0 & $\begin{array}{c}\text { Справжні та чагарникові } \\
\text { степи; псамофітна } \\
\text { рослинність; лісові } \\
\text { культури; байрачні діброви } \\
\text { та вільшаники; засолені } \\
\text { луки; болота }\end{array}$ & $\begin{array}{l}\text { Вирубання } \\
\text { дерев, } \\
\text { сінокосіння, } \\
\text { випасання } \\
\text { худоби, } \\
\text { випалювання }\end{array}$ \\
\hline Займанський & $\begin{array}{c}\text { Орнітологічний } \\
\text { ЗМЗ }\end{array}$ & 157.1 & $\begin{array}{l}\text { Справжні, засолені та } \\
\text { заболочені луки, } \\
\text { високотравні болота, } \\
\text { прибережно-водна та } \\
\text { справжня водна } \\
\text { рослинність }\end{array}$ & $\begin{array}{c}\text { Випас, } \\
\text { сінокосіння }\end{array}$ \\
\hline Орільський & $\begin{array}{c}\text { Гідрологічний } \\
\text { 3МЗ }\end{array}$ & 196.0 & $\begin{array}{c}\text { Справжні та заболочені } \\
\text { луки, водно-болотна } \\
\text { рослинність }\end{array}$ & $\begin{array}{c}\text { Випас, } \\
\text { сінокосіння }\end{array}$ \\
\hline Шевченків яр & $\begin{array}{c}\text { Ентомологічний } \\
\text { 3МЗ }\end{array}$ & 10.1 & $\begin{array}{c}\text { Справжні та чагарникові } \\
\text { степи; високотравні болота }\end{array}$ & $\begin{array}{c}\text { Випас, } \\
\text { сінокосіння }\end{array}$ \\
\hline Улянівський & $\begin{array}{c}\text { Ентомологічний } \\
\text { ЗМЗ }\end{array}$ & 8.4 & $\begin{array}{c}\text { Залишки справжніх степів, } \\
\text { лісові культури }\end{array}$ & $\begin{array}{c}\text { Терасування, } \\
\text { заліснення }\end{array}$ \\
\hline \multicolumn{5}{|c|}{ Території, зарезервовані для заповідання у складі Орільського екокоридору } \\
\hline Залінійний & $\begin{array}{c}\text { Гідрологічний } \\
\text { 3МЗ }\end{array}$ & 420.1 & $\begin{array}{c}\text { Справжні та чагарникові } \\
\text { степи; справжні, засолені та } \\
\text { болотисті луки; } \\
\text { прибережно-водна та водна } \\
\text { рослинність }\end{array}$ & $\begin{array}{c}\text { Випас, } \\
\text { сінокосіння, } \\
\text { вирубка дерев, } \\
\text { рекреація }\end{array}$ \\
\hline $\begin{array}{l}\text { Новопекельн } \\
\text { ий }\end{array}$ & $\begin{array}{c}\text { Гідрологічний } \\
\text { 3МЗ }\end{array}$ & 310.0 & $\begin{array}{c}\text { Справжні та чагарникові } \\
\text { степи; заплавні діброви; } \\
\text { справжні, засолені та } \\
\text { болотисті луки; } \\
\text { прибережно-водна та водна } \\
\text { рослинність }\end{array}$ & $\begin{array}{c}\text { Випас, } \\
\text { сінокосіння }\end{array}$ \\
\hline $\begin{array}{l}\text { Заплава } \\
\text { р. Оріль }\end{array}$ & $\begin{array}{c}\text { Водно-болотне } \\
\text { угіддя (ВБУ) }\end{array}$ & 1785.0 & $\begin{array}{c}\text { Справжні та чагарникові } \\
\text { степи; заплавні діброви та } \\
\text { вільшаники; справжні, } \\
\text { засолені та болотисті луки; } \\
\text { прибережно-водна та водна } \\
\text { рослинність }\end{array}$ & $\begin{array}{c}\text { Випас, } \\
\text { сінокосіння, } \\
\text { вирубка дерев, } \\
\text { рекреація }\end{array}$ \\
\hline
\end{tabular}




\begin{tabular}{|c|c|c|c|c|}
\hline \multicolumn{5}{|c|}{ Території, зарезервовані для заповідання у складі Берестового екокоридору } \\
\hline $\begin{array}{l}\text { Зачепилівськ } \\
\text { ий }\end{array}$ & $\begin{array}{c}\text { Орнітологічний } \\
\text { 3МЗ }\end{array}$ & 48.3 & $\begin{array}{c}\text { Справжні та засолені луки, } \\
\text { болота; прибережно-водна } \\
\text { та водна рослинність }\end{array}$ & $\begin{array}{c}\text { Випас, } \\
\text { сінокосіння }\end{array}$ \\
\hline $\begin{array}{l}\text { Заплава } \\
\text { p. Берестова }\end{array}$ & ВБУ & 2230.0 & $\begin{array}{c}\text { Справжні та засолені луки; } \\
\text { заплавні вільшаники; } \\
\text { болота; прибережно-водна } \\
\text { та водна рослинність }\end{array}$ & $\begin{array}{c}\text { Випас, } \\
\text { сінокосіння, } \\
\text { вирубання } \\
\text { дерев, } \\
\text { випалювання, } \\
\text { рекреація } \\
\end{array}$ \\
\hline
\end{tabular}

Урочище «Турецький вал» розташовано на степових схилах берега р. Оріль; урочище «Орчик» охоплює частину піщаної тераси 3 псамофітною рослинністю та лісовими культурами Pinus sylvestris, а вздовж р. Оріль та ії стариць, природні діброви з Quercus robur та вільшаники 3 Alnus glutinosa (L.) Gaerth.; урочище «Капінерне» розташовано у пониззі і вкрите рослинністю засолених луків та боліт. До складу рідкісної фітобіоти входить Stipa borysthenica Klokov ex Prokudin (ЧКУ), що утворює угруповання Stipeta borysthenicae, які належать до азональних угруповань піщаних степів, перебувають під загрозою зникнення і занесені до ЗКУ. На регіональному рівні охороняється угруповання засолених луків - Limonieta donetzici та 5 видів флори (табл. 2).

Таблиия 2

Раритетна фітобіота обстежених територій Зачепилівського району Харківщини

\begin{tabular}{|c|c|c|c|c|c|c|c|c|c|c|}
\hline \multirow[t]{2}{*}{ Назва виду } & \multicolumn{5}{|c|}{ Території ПЗФ } & \multicolumn{5}{|c|}{$\begin{array}{l}\text { Перспективні для } \\
\text { заповідання території }\end{array}$} \\
\hline & 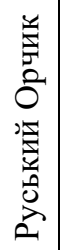 & 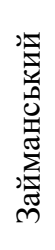 & 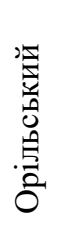 & 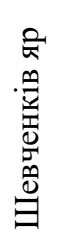 & 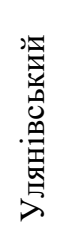 & ח & 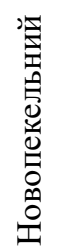 & 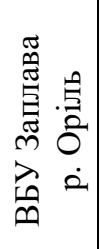 & 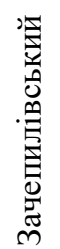 & 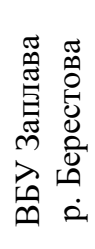 \\
\hline \multicolumn{11}{|c|}{ Угруповання, що занесені до ЗКУ } \\
\hline Stipeta borysthenicae & + & & & & & & & & & \\
\hline Stipeta capillatae & & & & & & + & + & + & & \\
\hline Stipeta lessingianae & & & & & & + & + & + & & \\
\hline Разом угруповань, занесених до ЗКУ & 1 & 0 & 0 & 0 & 0 & 2 & 2 & 2 & 0 & 0 \\
\hline \multicolumn{11}{|c|}{ Угруповання, що занесені до ЗСХ } \\
\hline Artemisieta santonicae & & + & & & & + & + & & & \\
\hline Fritilarieta (meleagroidis) graminosa & & + & + & & & & & & & \\
\hline Gladioletum (tenuis) graminosum & & + & & & & & & & & \\
\hline Glauceta maritimae & & + & & & & + & & + & + & + \\
\hline Hippureta vulgaris & & & & & & & & & + & + \\
\hline Inuleta helenii & & & + & & & & & & & \\
\hline Limonieta donetzici & + & + & + & & & & & + & + & + \\
\hline Limonieta alutacei & & + & & & & & & + & + & + \\
\hline Orchidoso-Gramineo-Cariceta & & & & & & & & & + & + \\
\hline Typheta laxmannii & & + & & & & & + & + & & \\
\hline
\end{tabular}




\begin{tabular}{|c|c|c|c|c|c|c|c|c|c|c|}
\hline Разом угруповань, занесених до ЗСХ & 1 & 7 & 3 & 0 & 0 & 2 & 2 & 4 & 5 & 5 \\
\hline \multicolumn{11}{|c|}{ Види, що занесені до ЧКУ } \\
\hline $\begin{array}{l}\text { Anacamptis palustris (Jacq.) R.M. Bateman, } \\
\text { Pridgeon et M.W. Chase }\end{array}$ & & & & & & & & & + & + \\
\hline Crambe aspera M. Bieb. & & & & + & & & & & & \\
\hline Dactylorhiza maculata (L.) Soo s.l. & & & & & & & & & + & + \\
\hline Gladiolus tenuis M.Bieb. & & + & & & & & & + & & \\
\hline $\begin{array}{l}\text { Fritillaria meleagroides Patrin ex Schult. et } \\
\text { Schult. f. }\end{array}$ & & + & + & & & & & + & & \\
\hline Ornithogalum boucheanum (Kunth) Asch. & & & & & & & + & + & & \\
\hline Stipa borysthenica Klokov ex Prokudin & + & & & & & & & & & \\
\hline Stipa capillata $\mathrm{L}$. & & & & & & + & + & + & & \\
\hline Stipa lessingiana Trin. et Rupr. & & & & & & + & + & + & & \\
\hline Tulipa quercetorum Klokov et Zoz & & + & & & & + & + & + & & \\
\hline Разом видів, занесених до ЧКУ & 1 & 3 & 1 & 1 & 0 & 3 & 4 & 6 & 2 & 2 \\
\hline \multicolumn{11}{|c|}{ Види, що занесені до ЧСХ } \\
\hline Allium flavescens Besser & & & & & & & + & + & & \\
\hline $\begin{array}{l}\text { Bellevalia sarmatica (Pall. ex Georgi) } \\
\text { Woronow }\end{array}$ & & & & & & & + & + & & \\
\hline Cirsium esculentum (Siev.) C. A. Mey. & + & + & + & & & + & & + & + & + \\
\hline Dryopteris filix-mas (L.) Schott & + & & & & & & & & & \\
\hline Glaux maritima $\mathrm{L}$. & & + & & & & + & & + & + & + \\
\hline Goniolimon tataricum (L.) Boiss. & & + & & & & & & & & \\
\hline Inula helenium $\mathrm{L}$. & & & + & & & & & & & \\
\hline Limonium donetzicum Klokov & + & + & + & & + & + & + & + & + & + \\
\hline Limonium platyphyllum Lincz. & + & + & & + & & + & & & & \\
\hline Pedicularis dasystachys Schrenk & + & + & & & & & & & & \\
\hline Rhaponticum serratuloides (Georgi) Bobrov & & + & + & & & & & & & \\
\hline Salvia aethiopis $\mathrm{L}$. & & & & & & + & & & & \\
\hline Salvia nutans L. & & & & & & + & & & & \\
\hline Salvia austriaca Jacq. & & & & & & & + & + & & \\
\hline Teucrium polium $\mathrm{L}$. & & & & + & & & + & + & & \\
\hline Typha laxmannii Lepech. & & + & & & & & + & + & & \\
\hline Разом видів, занесених до ЧСХ & 5 & 8 & 4 & 2 & 1 & 6 & 6 & 8 & 3 & 3 \\
\hline
\end{tabular}

\section{Орнітологічний заказник} «Займанський» розташований на лівобережній заплавній терасі p. Оріль 3 типовою для цих місцезростань строкатою рослинністю. Це мезофітні угруповання центральної частини заплави та гігрофітні по берегах стариць та Займанського лиману (див. табл. 1). До складу рідкісної флори заказника «Займанський» включені 3 лучні види 3 ЧКУ - Gladiolus tenuis M. Bieb., Fritillaria meleagroides Patrin ex Schult. et Schult.f., Tulipa quercetorum Klokov et Zoz та властиві переважно для засолених луків 7 угруповань із ЗСХ та 8 видів флори 3 ЧСХ (див. табл. 2).

Гідрологічний

заказник «Орільський» створений у заплаві однойменної річки. У його рослинному покриві представлений рідкісний лучний вид із ЧКУ (Fritillaria meleagroides) та 4 рідкісні для регіону види. Серед угруповань справжніх та заболочених луків - 3 належать до ЗСХ.

До складу ПЗФ Зачепилівського району включені 2 ентомологічні заказники. Це «Шевченків яр» та «Улянівський». Вони створені на степових схилах балок серед полів сільськогосподарських культур для 
охорони корисної ентомофауни. Схили балки у заказнику «Шевченків яр» вкриті типовими степовими угрупованнями зі значною участю лікарських медоносів та декоративних видів, серед яких Crambe aspera М. Bieb. (ЧКУ), Limonium platyphyllum Lincz. та Teucrium polium L. (ЧСХ). У зволоженому пониззі балки поширені угруповання Phragmites australis (Cav.) Trin. ex Steudel та видів Salix L. На території заказника «Улянівський» на початку 20 ст. було проведено заліснення. Схили балки терасовані, на них серед залишків степової флори окремими куртинами зберігся насаджений тут Fraxinus excelsior, а по днищу - його лісові культури. Рідкісна фітобіота представлена одним видом Limonium donetzicum Klokov (ЧCX) (див. табл. 2).

Територією Зачепилівського району проходять Берестовий та Орільский екокоридори місцевого значення - складові екомережі Харківщини [6]. Основне їх созологічне призначення збереження вільного розселення та міграції видів рослин і тварин між річковими долинами Сіверського Дінця та Дону, а також збереження біоти та безперервності ландшафтів екокоридорів у природному стані. Рослинний покрив екокоридорів формують переважно мезо- та гігрофітні трав'янисті ценози заплав річок. Незначні площі під заплавними дібровами та вільшаниками, на схилах надзаплавної тераси поширені угруповання справжніх та чагарникових степів.

У складі Берестового екокоридору зарезервований для наступ- ного заповідання орнітоло-гічний заказник «Зачепилівський», що планується створити на території водно-болотного угіддя «Заплава р. Берестова». У заказнику «Зачепилівський» представлена заплавна рослинність старичних озер, боліт, справжніх i засолених луків. Територія водно-болотного угіддя включає заболочене русло p. Берестова, мілководні затоки, старичні озера, болота, справжні та засолені луки і вільшаники у притерасних пониззях. На луках Берестового екокоридору відмічені місцезростання рідкісних видів Orchidaceae: Dactylorhiza maculata та Orchis palustris (ЧКУ), рослини засолених луків Cirsium esculentum, Glaux maritima, Limonium donetzicum (ЧСХ) а також лучні угруповання 3 3CX: Glauceta maritimae, Hippureta vulgaris, Limonieta donetzici, Limonieta alutacei, OrchidosoGramineo-Cariceta.

До Орільського екокоридору увійшли всі 3 існуючі території ПЗФ (Руський Орчик, Займанський, Орільський), що розташовані у заплаві Орілі. Планується створити 2 гідрологічні заказники місцевого значення «Залінійний» та «Новопекельний» та одне водно-болотне угіддя - «Заплава р. Оріль». Території гідрологічних заказників розташовані переважно у заплаві та вкриті угрупованнями справжніх та засолених луків, прибережно-водною та водною рослинністю, а також включають степові схили правого берега річки, де представлені угруповання справжніх та чагарникових степів. У «Новопекельному» незначна площа вкрита заплавною 
дібровою. На луках заказника «Залінійний» відмічено місцезростання Tulipa quercetorum, на степових схилах - Stipa capillata та S. lessingiana (ЧКУ), що утворюють типові угруповання справжніх злакових степів Stipeta capillatae та Stipeta lessingianaea, занесені до ЗКУ. У складі регіонально рідкісної фітобіоти угруповання засолених луків: Artemisieta santonicae та Glauceta maritimae та 6 видів рослин (табл. 2). У заказнику «Новопекельний», крім рідкісних видів та угруповань із ЧКУ та ЗКУ, що знайдені у «Залінійному» у заплавній діброві відзначене місцезростання Ornithogalum boucheanum (ЧКУ). До складу регіонально рідкісної флори нале-жать угруповання засолених луків та боліт: Artemisieta santonicae та Typheta laxmannii та 6 видів, що переважно зростають на степових схилах (див. табл. 2).

Водно-болотне угіддя «Заплава p. Оріль» включає заплаву з руслом p. Оріль та лиманами (Сомівський, Займанський, Скалонівський), старицями, заплавними озерами, болотами, луками, заплавними лісами, а також фрагменти справжніх степів на схилах надзаплавної тераси. Рідкісна фітобіота нараховує 6 угруповань - 2 ковилові угруповання справжніх степів Stipeta capillatae та Stipeta lessingianaea та 4 регіонально рідкісні, властиві для засолених луків (табл. 2), а також 12 рідкісних видів, серед яких Gladiolus tenuis, Fritillaria meleagroides, Tulipa quercetorum, Ornithogalum boucheanum, Stipa capillata та S. lessingiana 3 ЧКУ та 8 видів рідкісних на Харківщині, що зростають у степах та на засолених луках (див. табл. 2).

Майже на всіх досліджених територіях спостерігається антропогенний вплив (див. табл. 1). Трав'яниста рослинність заплавних лук та степових схилів частини заповідної площі може підлягати випасанню свійської худоби, випалюванню або сінокосінню. У заказнику «Улянівський» проведено терасування та заліснення схилів. У лісових фітоценозах антропогенний вплив пов'язаний 3 несанкціонованим вирубанням дерев. Навколо стариць, лиманів, русла річок місцями спостерігається надмірне рекреаційне навантаження.

\section{ОБГОВОРЕННЯ}

Відсоток заповідності Зачепилівського району є дуже низький $1.74 \%$. Це пояснюється загальною розораністю земель району, що сягає 70\%. Однак, природні та напівприродні території поширені на $24.4 \%$ площі [5], що дало підстави для пошуку на цих землях перспективних для заповідання територій та розробки проекту екологічної мережі Харківщини, як складової екологічної мережі України. Такі мало порушені ділянки зазвичай належать до сіножатей та пасовищ і розташовані у заплавах рр. Оріль і Берестова, де і запропоновано створити 3 перспективні для заповідання території та 2 ВБУ у складі запланованих екокоридорів місцевого значення.

Загальний фітосозологічний аналіз свідчить про ступінь репрезентативності раритетної фітобіоти на досліджених територіях. У складі 
рідкісної рослинності наявні 3 ри - 10 видів, включених до ЧКУ та угруповання з ЗКУ та 10 з ЗСХ, фло- 16 - до ЧСХ (табл. 3).

Таблиия 3

Порівняння раритетної фітобіоти існуючих та перспективних для заповідання територій

\begin{tabular}{|c|c|c|c|c|}
\hline \multirow[t]{2}{*}{ Ознака } & \multicolumn{4}{|c|}{ Кількість угруповань/видів раритетної фітобіоти } \\
\hline & 3КУ & $3 C X$ & ЧКУ & ЧCX \\
\hline Загальна кількість & 3 & 10 & 10 & 16 \\
\hline Території ПЗФ & 1 & 8 & 5 & 11 \\
\hline $\begin{array}{l}\text { Перспективні } \\
\text { території }\end{array}$ & 2 & 7 & 8 & 11 \\
\hline $\begin{array}{l}\text { Спільні } \\
\text { угруповання/види }\end{array}$ & 0 & 5 & 4 & 6 \\
\hline $\begin{array}{l}\text { Угруповання/види, } \\
\text { поширені лише на } \\
\text { перспективних для } \\
\text { заповідання } \\
\text { територіях }\end{array}$ & 2 & 2 & 5 & 4 \\
\hline
\end{tabular}

Регіонально рідкісні види репрезентують найбільш поширені у Зачепилівському районі природні фітоценози. На засолених, справжніх та болотистих луках відзначені 8 видів: Cirsium esculentum, Inula helenium, Glaux maritima, Goniolimon tataricum, Limonium donetzicum, Pedicularis dasystachys, Rhaponticum serratuloides, Typha laxmannii. На степових схилах трапляються 7 видів: Allium flavescens, Bellevalia sarmatica, Limonium platyphyllum, Salvia aethiopis, S. austriaca, S. nutans, Teucrium polium. Найчастіше на досліджених територіях представлені Limonium donetzicum, Glaux maritima та Cirsium esculentum (9,7 та 5 місцезростань, відповідно), досить часто - Tulipa quercetorum та Limonium platyphyllum (4 місцезростання).

Найбагатша рідкісна фітобіота на існуючих територіях відзначена в орнітологічному ЗМЗ «Займансь- кий» (7 угруповань 3 ЗСХ, 3 видів 3 ЧКУ, 8 - з ЧСХ), а серед зарезервованих - у Залінійному (2 угруповання із ЗКУ, 2 - із ЗСХ; 3 вид 3 ЧКУ, 6 - з ЧСХ), Новопекельному (2 угруповання із ЗКУ, 2 - із ЗСХ; 4 вид із ЧКУ, 6 - із ЧСХ), ВБУ «Заплава р. Оріль» (2 угруповання 3 ЗКУ, 4 - з ЗСХ; 6 видів з ЧКУ, 8 - 3 ЧСХ). Найменше фіторізноманіття властиве для ентомологічних 3М3 «Шевченків яр» (1 вид з ЧКУ, 2 - 3 ЧСХ) та «Улянівський» (1вид 3 ЧCX).

Дослідження природних та напівприродних територій дозволили оновити дані щодо ботанічної цінності існуючих об'єктів ПЗФ та виявити раніше невідомі місцезростання рідкісних рослинних угруповань та видів рослин. Кількісні показники рідкісної фітобіоти на існуючих та перспективних об’єктах приблизно однакові (див. табл. 3). На них зростає по 9 рідкісних угру- 
повань та 16 і 19 видів відповідно. Але на перспективних територіях були виявлені 4 угру-повання та 9 видів, що не охороняються на вже існуючих ПЗФ. Враховуючи, що кожен iз зазначених видів та угруповань зареєстрований на 1-3 заповідній або перспективній для заповідання територіях, вклю-чення останніх до ПЗФ збіль-шить не лише репрезентативність рідкісної фітобіоти на заповідних територіях Зачепилівського району, а й кількісні показники популяцій рідкісних видів, що знаходяться під охороною.

\section{ВИСНОВКИ}

1. У Зачепилівському районі Харківщини на загальній площі 1377.6 га створені 5 об' єктів ПЗФ, де зростає 9 рідкісних рослинних угруповань (ЗКУ, ЗСХ) та 16 видів рари-тетної флори (ЧКУ, ЧСХ).

2. Ботанічні обстеження природних та напівприродних територій дозволили виділити 5 перспективних для заповідання об'єктів, де зростає 9 рідкісних рослинних угруповань (ЗКУ, 3СХ) та 19 видів раритетної флори (ЧКУ, ЧСХ).

3. Найбагатша рідкісна фітобіота на існуючих територіях відзначена в орніто-логічному 3М3 «Займанський» (7 угруповань із 3СХ, 3 видів 3 ЧКУ, 8 - з ЧСХ), серед перспективних територій - у ВБУ «Заплава р. Оріль» (2 угруповання з ЗКУ, 4- 3 ЗСХ; 6 видів з ЧКУ, 8 - з ЧСХ).

4. Дослідження перспективних для заповідання територій дозволили виявити раніше невідомі місцезростання рідкісних рослинних угруповань та видів рослин. Це місцезростання 4 угруповань та 9 видів рослин, що не охороняються на існуючих ПЗФ.

5. Включення перспективних для заповідання обстежених територій до ПЗФ збільшить не лише репрезентативність рідкісної фіто-біоти на заповідних територіях Зачепилівського району, а і кількісні показники популяцій рідкісних видів, що знаходяться під охороною.

\section{Список використаних джерел}

1. Geobotanichne rajonuvannya Ukrayinskoyi RSR. (1977) Kiyiv: Nauk. Dumka.

2. Gorelova L.N., Alehin A.A. (2002) Rastitelnyj pokrov Harkovshiny. Harkov.

3. Zelena kniga Ukrayini (2009) Kiyiv: Alterpres.

4. Nadtochij G.S., Filatova O.V., Klimov O.V. (2009) Zberezhennya raritetnogo bioriznomanittya $\mathrm{V}$ Orilskomu ekokoridori ekomerezhi Harkivskoyi oblasti. Matereriali Vseukrayinskoyi Naukovoyi Konferenciyi: Zoologichna nauka u suchasnomu suspilstvi. Kiyiv-Kaniv, p. 330-333.

5. Prirodno-zapovidnij fond Harkivskoyi oblasti (2005) Harkiv: Rajder.

6. Ekologichna merezha Harkivskoyi oblasti (2008) Posibnik. Harkiv.

7. Chervona kniga Ukrayini. Roslinnij svit (2009) Kiyiv: Globalkonsalting.

8. Diamond Joshua M., Heinen Joel T. (2016) Conserving rare plants in locally-protected urban forest fragments: A case study from Miami-Dade County, Florida. Urban Forestry \& Urban Greening. 20(1): $1-11$ https://doi.org/10.1016/j.ufug.2016.07.008

9. Schalkwyk J. van, Pryke J.S., Samways M.J. (2019) Contribution of common vs. rare species to species diversity patterns in conservation corridors. Ecological Indicators. 104: 279-288. https://doi.org/10.1016/j.ecolind.2019.05.014

10. Vernon H. Heywood. (2019) Conserving plants within and beyond protected areas - still problematic and future uncertain. Plant Diversity. 41(2): 36-49. https://doi.org/10.1016/j.pld.2018.10. 
UDC 502.75 (477.54)

\section{REPRESENTATIVE ANALYSIS OF RARE PHYTOBIOTS IN EXISTING AND FORWARD- LOOKING PRESERVATION AREAS IN ZACHEPYLIVSKIY DISTRICT IN KHARKIV}

Filatova O.V., Gontova T.M., Rudenko V.P.

Relevance of diversity researches in natural and urban protected landscapes is widely recognized in world. The aim of our work was to study the current state of the rare phytobiota of protected and promising objects of one of the most plowed areas of Kharkiv district-Zachepilovsky.

This article represents the results of phytobiots studies in 5 preservation areas of Zachepylivskyi district in Kharkiv region and in 5 perspective sanctuary zones, which are planned to be created as a part of the ecological network. Almost all surveyed territories have remained in a slightly disturbed state. They give a fulfilling representation of the natural vegetation in studied zone: true and shrub steppes, floodplain oak and alder forests, saline and marshy meadows, coastalaquatic and aquatic vegetation. The rare phytobiots include 13 protected plant groups, three of which (Stipeta capillatae, Stipeta lessingianaea, Stipeta borysthenicae), are listed in the Green Book of Ukraine and 26 species of rare flora, 10 of which are listed in the Red Book of Ukraine: Anacamptis palustris (Jacq.) R.M. Bateman, Pridgeon et M.W. Chase, Crambe aspera M. Bieb., Dactylorhiza maculata (L.) Soo s.l., Gladiolus tenuis M. Bieb., Fritillaria meleagroides Patrin ex Schult. et Schult.f., Ornithogalum boucheanum (Kunth) Asch., Stipa borysthenica Klokov ex Prokudin, S. capillata L., S. lessingiana Trin. et Rupr., Tulipa quercetorum Klokov et Zoz. The largest degree of rare phyto-diversity was perceived in wetland area - the Orel River Flood, where 2 groups from the Green Book of Ukraine, 4 groups from the Green List of Kharkiv region, 6 rare species from the Red Book of Ukraine and 8 from the Red List of Kharkiv region are growing.

Key words: rare flora, plant communities protection, ecological network, natural reserve fund, Kharkiv region.

Стаття надійшла 11. 10. 2019 р. Рекомендована до друку на засіданні редакиійної колегї після рещензування 